\title{
Self-sufficiency of agriculture in Finland in 1970-1983
}

\author{
LAURI KETTUNEN \\ Agricultural Economics Research Institute, Luutnantintie 13, \\ SF-00410 HELSINKI, Finland
}

\begin{abstract}
This study is aimed at considering self-sufficiency and food security in Finland. Self-sufficiency of final products has been over $100 \%$ for a long period. Only self-sufficiency of fruits and vegetables is below $100 \%$ due to the climate. Self-sufficiency of energy, protein and fat of the diet is also examined in this article. A new indicator of total self-sufficiency is developed by dividing the total yield measured in feed units with the total feed requirement of total human consumption, measured also in feed units. According to these calculations total self-sufficiency has been from $105 \%$ to $130 \%$, depending on the quantity of total yield.

It is difficult to make adequate calculations of self-sufficiency of inputs, since the industry producing agricultural inputs is operating under free trade, and tries to benefit from foreign trade. Imports of energy, raw materials, machines and implements lower self-sufficiency. Some estimates are, however, given in the text.

The article also discusses the attempts to improve food security by storage. Agricultural research aims to clarify how alternative cultivation methods could lessen the dependence on imports, and thus improve the food security.
\end{abstract}

Index words: self-sufficiency, food security, self-sufficiency of inputs

\section{Introduction}

Self-sufficiency as a concept is rather clear. Dictionaries define self-sufficiency as an economy which is cabable of providing for its own needs. Earlier, households were self-sufficient. They were able to produce all things at home. Food, clothing, housing and implements were made on the farm or in the home. Only some exchange was necessary. Self-sufficiency was high in households and it was even higher when the nation as a whole was examined.

However, times have changed. The level of consumption has increased considerably but at the same time a self-sufficiency economy has been changed to an exchange economy. Few farms are self-sufficient with respect to food. The making of clothing in high income countries is small. There are no sheep and flax cannot be cultivated. The self-sufficiency of our economy has declined.

National self-sufficiency has also decreased considerably in small countries. Economists have shown the profitability level in the national division of labour and therefore foreign trade has expanded continuously. It has im- 
proved the economic welfare but at the same time, self-sufficiency has decreased. For example, foreign trade is about one-third of the national income in Finland. Many important raw materials and energy are imported. The situation is not threatening as long as foreign trade continues without interruption, but the stoppage of imports would seriously destroy or disturb our everyday life.

The situation is not as difficult in large countries, because there foreign trade is only a small percentage of Gross National Product. They have their own raw materials and energy even though part of their raw materials are imported. Particularly the high level of technology raises the requirements of self-sufficiency. Poor countries are, in principle, less dependent. Their economy will not collapse even though foreign trade would stop. The economies of rich countries would suffer most, even though, in times of crisis, they may maintain a higher economic level than poor countries because of their technology.

Self-sufficiency in food is of major importance for most economies. A man can give up many things, but not food. There has been a lot of discussion over food self-sufficiency or food security in Finland recently. Particularly, the energy crisis and the simultaneous food crisis has led officials, as well as ordinary people, to begin to question whether there will be food in the future. Is our extra supply only nominal, which may disappear if the time comes when the borders are closed? These questions over self-sufficiency have led to a more thorough consideration than has previously been made.

\section{The purpose of the study}

The purpose of the study is to examine selfsufficiency of agriculture in 1970-1983. The study concerns the final products, agricultural inputs and the whole of agriculture in general. The article is based on the study by the author (Kettunen 1986 b).

Self-sufficiency ratio of individual products have been calculated for a long time by the
Marketing Research Institute of Pellervo Society (cf. ANON 1982). It can be done easily for animal products. Self-sufficiency is defined simply as a ratio of production and consumption. For example, the self-sufficiency of meat can be easily calculated. However, the compilation of statistics has been developed sufficiently only in recent decades so, no confident long time series can be found. This study has been confined only to the last $10-14$ years. This is sufficient for many development studies since the change from the 1960 's to 1970 's meant a great change in agriculture.

Self-sufficiency studies have been directed mainly at final products. Energy crises have meant, however, that our agriculture is threatened mainly by the shortage of inputs. The use of fertilizers and machinery has increased but since both are imports, self-sufficiency has fallen in the most critical places (LAAKSONEN \& KETTUNEN 1981). Therefore it is also necessary to study the self-sufficiency of inputs.

The study is based mainly on simple balance sheets, such as food balance sheets. However, some modifications have been necessary.

\section{Methods}

Self-sufficiency (SS) is usually measured as percentage which is obtained by the division of national production (Q) by consumption (C): $\mathrm{SS}=\mathrm{Q} / \mathrm{S}$. This is the so-called national self-sufficiency ratio. Self-sufficiency could be defined in many ways. A quoted reference is the study by FAO (1975). The difficulty with more complex definitions is that the data requires quite a lot of modifications which may not be easily carried out. On the other hand, the repetition of the study may be difficult and therefore the continuation of the time series may be difficult. Therefore it may be better to use the simple definition in spite of its deficiencies.

Self-sufficiency ratios of individual products are the most common way of measuring self-sufficiency. However, people are often concerned about the total self-sufficiency of 
agriculture. These types of calculations are seldom made. It is possible to calculate the self-sufficiency according to the energy, protein and fat content of the diet. These calculations are also made in this study.

A special indicator of the self-sufficiency is calculated in this study, which shows how well domestic plant production satisfies domestic consumption. Plant production is the basis for the whole of agriculture. A part of it is directly consumed, but a part is processed into animal products. Food security depends mainly on how plant production is functioning, since animal production is not so sensitive to risks once the supply of feed is secured.

The self-sufficiency of inputs is more difficult to calculate. For example, machines are often made of imported raw materials or parts (LAAKSONEN 1985). Therefore the ratio of domestic production and domestic use does not necessarily indicate the self-sufficiency of machinery. The simple definition has, however, been used in this study. On the other hand, it may be noted that some of the imports of spare parts or raw materials may be of domestic origin because of the complicated structure of foreign trade. The self-sufficiency of energy is perhaps the most critical, with respect to food security. Some calculations as to the self-sufficiency of energy can be made by using the imports of oil and electricity, as has been the case in this study. For most of the inputs the self-sufficiency ratios are only indications.

The self-sufficiency ratios have been calculated on a calendar year basis. This is sometimes a poor indicator. For example, in the case of grains, the production year might be a better time period. Arithmetic methods also effect the self-sufficiency ratios. Sometimes it is possible to calculate the ratios on a net or gross basis. For example, grain production and consumption can be calculated in either of these ways. Production may include seed and waste. Also, consumption may include both of these items. Alternatively, production may be calculated in net terms by subtracting seed and waste. Similarly, the same can be done with consumption. Using net or gross figures gives, however, different results. Therefore a careful use of self-sufficiency ratios requires a clear definition of concepts.

\section{Self-sufficiency of final products}

\subsection{Individual products}

There are various methods available to calculate the self-sufficiency of grains. In this study the production of grains for human consumption (or supply) has been calculated by estimating the grain supply available for human consumption and subtracting the seed value from this. The grain supply for human consumption of the total yield varies from year to year depending on harvesting and other climatic factors. Every year the Board of Agriculture estimates the percentage which implies the quality of grains for human consumption. The rest of the yield is used for animal feeding. When the seed is subtracted from this quantity, we get the final supply of grain for human consumption. This is then divided by consumption which should be measured in grains (see Table 1).

The self-sufficiency of wheat has varied from 180 to $20 \%$. The year 1981 was particularly bad when almost all of the production was of such low quality that it was only good enough for animal feed. The area for wheat production also fell considerably at the

Table 1. Self-sufficiency of grains in $1970-83, \%$.

\begin{tabular}{lrrrrr}
\hline Year & Wheat & Rye & Barley & Oats & Sugar \\
\hline 1970 & 105 & 87 & 98 & 107 & 27 \\
1971 & 125 & 100 & 105 & 117 & 29 \\
1972 & 117 & 92 & 119 & 103 & 38 \\
1973 & 137 & 102 & 98 & 96 & 35 \\
1974 & 117 & 94 & 98 & 101 & 39 \\
1975 & 181 & 63 & 125 & 120 & 45 \\
1976 & 160 & 155 & 131 & 121 & 40 \\
1977 & 60 & 63 & 123 & 92 & 39 \\
1978 & 18 & 54 & 117 & 101 & 54 \\
1979 & 54 & 62 & 110 & 111 & 45 \\
1980 & 110 & 110 & 94 & 101 & 55 \\
1981 & 23 & 30 & 80 & 84 & 51 \\
1982 & 128 & 26 & 111 & 115 & 53 \\
1983 & 176 & 106 & 136 & 129 & 74 \\
\hline
\end{tabular}


end of the 1970's which also lowered the supply of wheat. In recent years the production has recovered to some extent, but imports have been necessary to satisfy human consumption. Wheat is also used for some industrial purposes which increases the need for domestic production.

The self-sufficiency for rye has almost always been below $100 \%$. The area of rye cultivation has decreased and there seem to be difficulties in keeping the rye area around 50,000 or 60,000 hectares which is required for domestic self-sufficiency.

Self-sufficiency in feed grains has been approximately $100 \%$. In some bad years production has fallen below the domestic requirements and imports have been necessary. The years 1973 and 1981 were particularly bad and then feeds had to be imported. Of course, part of the imports of feed are always needed since, for example, protein is insufficient in the domestic grains. Soyabean meals and fish meal are the normal imports. In addition, part of the imports are needed to keep up export production.

Concerning plant production, there are some products which cannot be cultivated to a sufficient extent in Finland. The self-sufficiency of sugar is 50 to $60 \%$ and particularly the self-sufficiency of fruits and vegetables is always far below $100 \%$. Only apples and some plums are cultivated in Finland, but most of the citrus products and tropical fruits have to be imported. Also vegetables like tomatoes and cucumbers are imported in the winter time.

However, where animal products are concerned (Table 2), the picture is quite different. Self-sufficiency of milk has been over $120 \%$ and has risen in recent years to about $130 \%$. Also the self-sufficiency of meat has usually been above $100 \%$. Especially pork production can be easily raised and there are pressures to do so. With the help of all kinds of supply restrictions the production of pork has been able to remain at a reasonable level. Beef production has been above the domestic consumption in recent years, but due to the de-
Table 2. Self-sufficiency of milk, beef, pork and eggs in $1970-83$.

\begin{tabular}{lcrcc}
\hline Year & Milk & Beef & Pork & Eggs \\
\hline 1970 & 125 & 110 & 110 & 136 \\
1971 & 121 & 113 & 127 & 151 \\
1972 & 122 & 105 & 119 & 147 \\
1973 & 122 & 93 & 109 & 156 \\
1974 & 125 & 111 & 109 & 151 \\
1975 & 120 & 98 & 101 & 155 \\
1976 & 124 & 101 & 111 & 165 \\
1977 & 131 & 99 & 108 & 166 \\
1978 & 128 & 101 & 117 & 138 \\
1979 & 125 & 99 & 119 & 137 \\
1980 & 129 & 102 & 120 & 140 \\
1981 & 125 & 113 & 128 & 153 \\
1982 & 122 & 110 & 126 & 159 \\
1983 & 133 & 116 & 118 & 165 \\
\hline
\end{tabular}

cline of dairy herds, beef supply will not rise. It may even fall slightly in the future.

The self-sufficiency of eggs has been the highest. It has been around 150 to $160 \%$ and recent developments indicate that production will fall.

\subsection{Total self-sufficiency}

It is slightly difficult to make any summary or total figures of self-sufficiency for agriculture as a whole. If we look at the calorie consumption the self-sufficiency (Table 3 ) ratios fall below $100 \%$ in most years. This result is due to the imports of sugar which make up about $13 \%$ of total calorie consumption. Within total agriculture production sugar or sugar beet is a minor product and the area is only about $1.5 \%$. Therefore, the self-sufficiency ratio for energy gives a biased picture of total self-sufficiency for Finnish agriculture.

In this study a special summary indicator has been developed to examine the real selfsufficiency. For that purpose, the total requirement of plant production for the whole diet is calculated. The majority of plant production goes to animal production, but a part of it is also consumed directly. Total production, measured in feed units divided by the diet, also measured in feed units, gives an indication of the agriculture needed to satisfy domestic con- 
Table 3. Self-sufficiency of energy, protein and fat and total self-sufficiency (see the text) in 1970$83, \%$.

\begin{tabular}{lrrrr}
\hline Year & Energy & Protein & Fat & Total \\
\hline 1970 & 92 & 109 & 104 & 112 \\
1971 & 91 & 108 & 104 & 114 \\
1972 & 95 & 112 & 102 & 111 \\
1973 & 90 & 107 & 98 & 105 \\
1974 & 96 & 114 & 101 & 104 \\
1975 & 93 & 112 & 96 & 108 \\
1976 & 107 & 124 & 103 & 126 \\
1977 & 84 & 104 & 105 & 105 \\
1978 & 82 & 99 & 104 & 109 \\
1979 & 78 & 98 & 103 & 111 \\
1980 & 94 & 111 & 110 & 114 \\
1981 & 84 & 100 & 113 & 93 \\
1982 & 93 & 110 & 115 & 114 \\
1983 & 110 & 117 & 121 & 130 \\
\hline
\end{tabular}

sumption by domestic production. This index shows that the total self-sufficiency of agriculture has been about $115 \%$ on average (Table 3), but the variation is very large. In 1981 the self-sufficiency was only $93 \%$ whereas in 1983 the corresponding figure was $130 \%$. This result can be easily explained by the large variation in total yield.

\section{Self-sufficiency of inputs}

The trade and industries producing agricultural inputs operate in the free economy under free competition. They buy their raw materials, inputs and articles with economic grounds. Foreign trade is a part of their actions, as it is in the whole economy. Therefore, it is quite natural that the self-sufficiency of inputs is clearly under $100 \%$.

It may be necessary to point out in the beginning that in 1983 the greatest share of all costs was purchased feed $(27.4 \%$, KETTUNEN 1986 a). The next largest share was the machine and implement costs (23.2 \%), after that fertilizers $(12.9 \%)$, mending costs $(7.7 \%$ ) and general costs $(6.7 \%)$ as well as fuel $(5.7 \%)$. These account for $83.6 \%$ of total costs which do not include the labour input of the family or the interest rate on the owners' capital. As to self-sufficiency, the most important parts of costs are fertilizers, pur- chased feed, fuel, electricity and machine costs.

Even though there is domestic industry in agricultural machines and implements, about half of all machines sold are imported, i.e. the share of domestic machines has been only $40-44 \%$. Finnish agricultural machines are, however, exported to a growing extent, which means that the total self-sufficiency with respect to machines is about $50 \%$.

The self-sufficiency of feed is close to $100 \%$ even though it is slightly below, since part of the protein feed is imported. Also in bad years some feed, such as corn, has been imported.

Fertilizers are the most critical input with respect to a crisis. Their self-sufficiency is considered to be low. The energy and ammonia needed for the nitrogen industry is imported. Part of the raw materials of other fertilizers are also imported. Phosphates are important in agriculture. Nowadays Finland is almost self-sufficient in this respect after the opening of a new mine. Thus the most critical input is energy.

Sizeable research is being carried out to improve the use of biological nitrogen in agriculture. The problem is that agriculture is specialised, and therefore the use of plants producing nitrogen is not possible everywhere. However, it would be possible to improve selfsufficiency by the biological binding of nitrogen.

Pesticides are also important in agriculture nowadays. Domestic production satisfies the needs, but a part of the raw materials are imported, which is, of course, a weak point in our food security.

It is difficult to estimate what the real energy self-sufficiency would be in a crisis. At the moment, agriculture is based on imported energy such as oil or electricity. In a crisis situation, oil could be substituted by domestic energy resources such as wood or biomass. Their adaptation would, however, take a lot of time and self-sufficiency would fall during the years after the beginning of the crisis. Again, research is being carried out to im- 
prove the utilisation of domestic resources for fuel of tractors.

It is difficult to make any summary estimate of self-sufficiency of inputs. Namely, energy is very important in this respect. If there is a lack of energy, tractors would stop and agricultural production would totally collapse. Domestic resources can be a substitute for imported energy, but there is no clear picture as to how much time would be needed to adjust to a crisis situation. Other critical inputs are the raw materials for pesticides and fertilizers, even though they would not create such a large problem as energy. A rough estimate of the self-sufficiency of inputs can be given: the value of imported inputs is about $15 \%$ of the value of all inputs.

\section{Improvement of food security}

\subsection{Actions by the Government}

The increase of grain stores is perhaps the most concrete action by the government to increase food security. The aim of the State Granary is to stabilize grain markets in Finland by storage. A few years ago, an Act of Parliament was passed which implies that a part of the stores are security stores; i.e. they can only be used with the permission of parliament in a time of crisis.

The target is to provide security stores of 400 mill. $\mathrm{kg}$ of bread grains and 600 mill. $\mathrm{kg}$ of feed grains. These amounts cover the consumption of bread grains for one year and the commercial sales of feed grains for about half a year. The store capacity of the State Granary may, of course, be higher. In fact, it was about 1200 mill. $\mathrm{kg}$ in 1984 . Private commercial firms as well as farmers also have stores, and so the total storage capacity is much larger than that of the State Granary. The most critical point in food security is in the summer, just before the new crop. Stores have to be sufficient to cope with a total crop failure. Of course, such a failure or the collapse of farming is quite unlikely. Some forage (hay, silage) is always obtained, as well as feed grains in most cases, and feed grains can also be used for human consumption.

The government has also planned for the storage of some critical raw materials and spare parts, but no significant results have so far been reached. Oil reserves have been built up constantly, a part of which are available for agriculture, so fuel for tractors is secured at least in the short run. The same applies for the energy required for the fertilizer industry.

\subsection{Other readiness for crisis}

Energy is the most central input with respect to crisis management. Agriculture uses both oil and electricity. A part of electricity is domestic (hydroelectric power and electricity produced by other domestic sources such as wood and peat), so that a complete lack of energy is unlikely even though shortages may become evident even in agriculture.

The fuel for tractors is, of course, most problematic. It can be assumed that during normal conditions oil will not be substituted by domestic energy sources, and oil will be used for as long as it is available. In the case of shortage, however, there are substitutes. Carbon monoxide was used during the last war, and its application has been studied and improved in recent years. Its application in agriculture in a crisis would be a comprehensive task, particularly if all car and truck traffic should use the same technology. The transfer is, of course, possible, but it would take many years. During the transfer period, old technology has to be used partly with stored oil, if the borders remain closed. The preparedness to transfer to domestic energy has improved in recent years, but it is still not very good. Self-sufficiency in energy will not, however, improve during normal peace conditions, and oil will continue to be imported in the future.

\subsection{Fertilizer and other chemical industries}

The Finnish fertilizer industry produces all fertilizers used in the country but the production is based on imported energy and raw ma- 
terials. Should the borders be closed, production of fertilizers will fall quite quickly. In the long run, a fall in yields will follow. Energy may be substituted by domestic energy, even though it may take time.

The fertilizer industry uses oil as a raw material in making nitrogen. Finland could use peat instead of oil. In recent years plans have been made to return to the use of peat so that self-sufficiency will improve.

Phosphate is another critical raw material in fertilizer products. Domestic raw materials are available and self-sufficiency can easily be increased up to $100 \%$. A decrease in the use of phosphate would not be critical since its use has been too high and it stays a long time in the soil. The yield level would not fall due to the shortage of phosphates.

The situation is worse in the case of potash. So far, no economic raw materials have been found in Finland. But in a short crisis the shortage of potassium fertilizer may not be sufficiently critical as to lower the yield level considerably.

The self-sufficiency of other chemicals (pesticides, herbicides) used in plant production is low. The effect of plant production is very great, so the use of pesticides and herbicides would be profitable, even in the case of higher prices through possible domestic production.

\subsection{Alternative farming methods}

The dependence of the fertilizer industry on imported energy and raw materials has caused a lot of discussion and research into the development of natural or alternative farming methods. Nitrogen fertilizers require much energy. Leguminous plants and clover can bind nitrogen in the soil which can then be used by other plants.

A comprehensive use of these plants seems to face many problems. Modern farming has become very specialized, whereas natural farming requires mostly mixed farming. At the moment, there are no signs that natural farming will increase to the extent that it will be of significant importance to self-suffi- ciency. It requires a long time period to introduce alternative farming technology. However, in a crisis situation good advice may be more readily acceptable to farmers than in normal conditions.

It is to be remembered, however, that the energy used by the fertilizer industry is only a small part of the energy needed by agriculture. Fertilizer production should be secured to the maximum amount since it is the most effective input in agriculture.

\subsection{Adaptation of consumption}

The diet in industrialized countries is very energy consuming. Consumption has moved from plant products to animal products, which means a larger use of resources than earlier. The waste of energy when beef is substituted for wheat is over $90 \%$. The national diet can be changed, without any nutritional loss, to favour a greater consumption of plant products; including a rather large self-sufficiency reserve which can be utilized in a crisis.

A minimum requirement diet has been planned for crisis periods which fulfills all nutritional requirements. Its energy content is about the same as that of a normal diet, but it consists of different food items. There are equal amounts of milk and milk products in it as in the present diet, more grain products and less meat and fat.

It is, of course, difficult to know how to encourage people to adopt the crisis diet plan. It should be possible to implement it by regulation, but all kinds of rationing easily brings about a black market, which weakens the effect of rationing. In any case, it is possible to adjust consumption to the crisis situation without large nutritional problems.

Attempts will be made to maintain milk production during a crisis since it is a major protein source. Pork and egg production can be decreased considerably, however, because their normal production level can be restored rather easily. This is not the case in milk production since the raising of a dairy stock is a slow process. 


\section{References}

ANON 1982. PSM:n viisi vuosikymmentả. PellervoSeuran Markkinatutkimuslaitos. Kouvola 1982, 80 p.

FAO 1975. Self-sufficiency in Food and Food Commodities. International Agricultural Adjustment, C. 75/ LIM/1, October 1975. 62 s. + 4 liit.

Kettunen, L. 1986 a. Finnish Agriculture in 1986. Agr. Econ. Res. Inst., Publ. 50. Helsinki 1986, 42 p.

Kettunen, L. 1986 b. Maatalouden omavaraisuus Suomessa vuosina 1970-83. Summary: Self-sufficiency of Finnish Agriculture in 1970-83. Agr. Econ. Res. Inst.,
Publ. 49. Helsinki 1986, 75 p.

LAAKSONEN, K. 1985. Maatalouden tuontipanosten korvaaminen kotimaisilla raaka-aineilla. Pellervon taloudellisen tutkimuslaitoksen julkaisuja No. 5. Espoo 1985.

LAaKsonen, K. ja Kettunen, L. 1981. Maatalouden huoltokyky. Esitutkimus. Pellervon taloudellisen tutkimuslaitoksen raportteja ja artikkeleita No. 14. Espoo 1981, $77 \mathrm{p}$.

Ms. received August 15, 1986.

\section{SELOSTUS}

\section{Maatalouden omavaraisuus Suomessa vuosina $1970-1983$}

\section{Lauri Kettunen}

Maatalouden taloudellinen tutkimuslaitos

Luutnantintie 13, $00410 \mathrm{Helsinki}$

Artikkelissa tarkastellaan maatalouden omavaraisuutta ja huoltovarmuutta. Lopputuotteiden omavaraisuus on ollut yleensă yli $100 \%$ ja vain hedelmien ja vihannesten omavaraisuus on jäänyt selvästi alle $100 \%$. Artikkelissa on laskettu myös ruokavalion energia-, valkuais- ja rasvaomavaraisuus.

Artikkelissa esitelläăn myős koko maatalouden omavaraisuutta varten kehitetty indikaattori. Se on laskettu jakamalla koko sato (rehuyksikköinä mitattuna) elintarvikkeiden kulutukseen tarvittavalla sadon määrällä (myös rehuyksikkőină mitattuna). Sen mukaan kokonaisoma-

varaisuus on vaihdellut 105 ja $130 \%$ välillä.

Tuotantopanosten omavaraisuudesta on esitetty myös joitain arvioita, joskin on todettava, ettả esitetyt luvut ovat hyvin likimääräisiä. Lopuksi artikkelissa tarkastellaan omavaraisuuden parantamiseen tăhtăăviă toimenpiteitä.

Artikkeli perustuu tekijän aikaisemmin julkaisemaan tutkimukseen: Maatalouden omavaraisuus Suomessa vuosina 1970-83, Maatal. tal. tut. lait. julk. no. 49, Helsinki 1985. 